\title{
Neonatal Pertussis, an Under-Recognized Health Burden and Rationale for Maternal Immunization: A Systematic Review of South and South-East Asian Countries
}

\author{
Ashish Agrawal (D) - Sanjeev Singh · Shafi Kolhapure \\ Walid Kandeil · Rishma Pai · Tanu Singhal
}

Received: February 5, 2019 / Published online: May 3, 2019

(C) The Author(s) 2019

\begin{abstract}
Pertussis is an under-recognized cause of neonatal morbidity and mortality. To review information on the epidemiology and disease burden of neonatal pertussis in South and Southeast Asian countries, a systematic literature review of three bibliographic databases was undertaken. Peer-reviewed original studies on neonatal pertussis epidemiology and burden published since 2000, with a geographical scope limited to South and Southeast Asian countries, were included. Data were systematically extracted based on parameters defined a priori. Our findings show that the burden of neonatal pertussis and its complications is substantial. An increase in the number of pertussis cases has
\end{abstract}

Enhanced digital features To view enhanced digital features for this article go to https://doi.org/10.6084/ m9.figshare.7951187

A. Agrawal $(\square) \cdot$ S. Singh · S. Kolhapure

Medical Affairs Department, GSK, Mumbai, India e-mail: ashish.8.agrawal@gsk.com

W. Kandeil

R\&D Department, GSK, Wavre, Belgium

R. Pai

Lilavati, Jaslok, and Hinduja Hospitals, Mumbai, India

T. Singhal

Kokilaben Dhirubhai Ambani Hospital, Mumbai, India been noted since early 2000, ranging from 61 to $92.9 \%$ in infants $0-3$ months old. The most common symptoms an infant is likely to present with are cough with or without paroxysms, cyanosis, apnea, tachypnea, difficulty in breathing and leukocytosis. In addition, it can lead to hospitalization (length of stay: 5-7 days), complications (e.g., pneumonia, seizures) and mortality ranging from 5.6 to $14.7 \%$. Other observations indicate that diagnosis is challenging because of non-specific clinical symptoms. Specifically, for obstetricians and gynecologists, the information available for making informed decisions on the prevention of neonatal pertussis is unreliable. Maternal immunization against pertussis during late stages of pregnancy has proven to be efficacious and well tolerated. A high burden of neonatal pertussis, as well as its complications, is observed in South and Southeast Asian countries. There is a need to intensify efforts to protect this vulnerable population with maternal vaccination.

Funding: GlaxoSmithKline Biologicals SA

Plain Language Summary: Plain language summary available for this article. Please see Fig. 1 and the following link: https://doi.org/10. 6084/m9.figshare.7951187.

Keywords: Asia; Epidemiology; Maternal Immunization; Neonatal; Newborns; Pertussis 


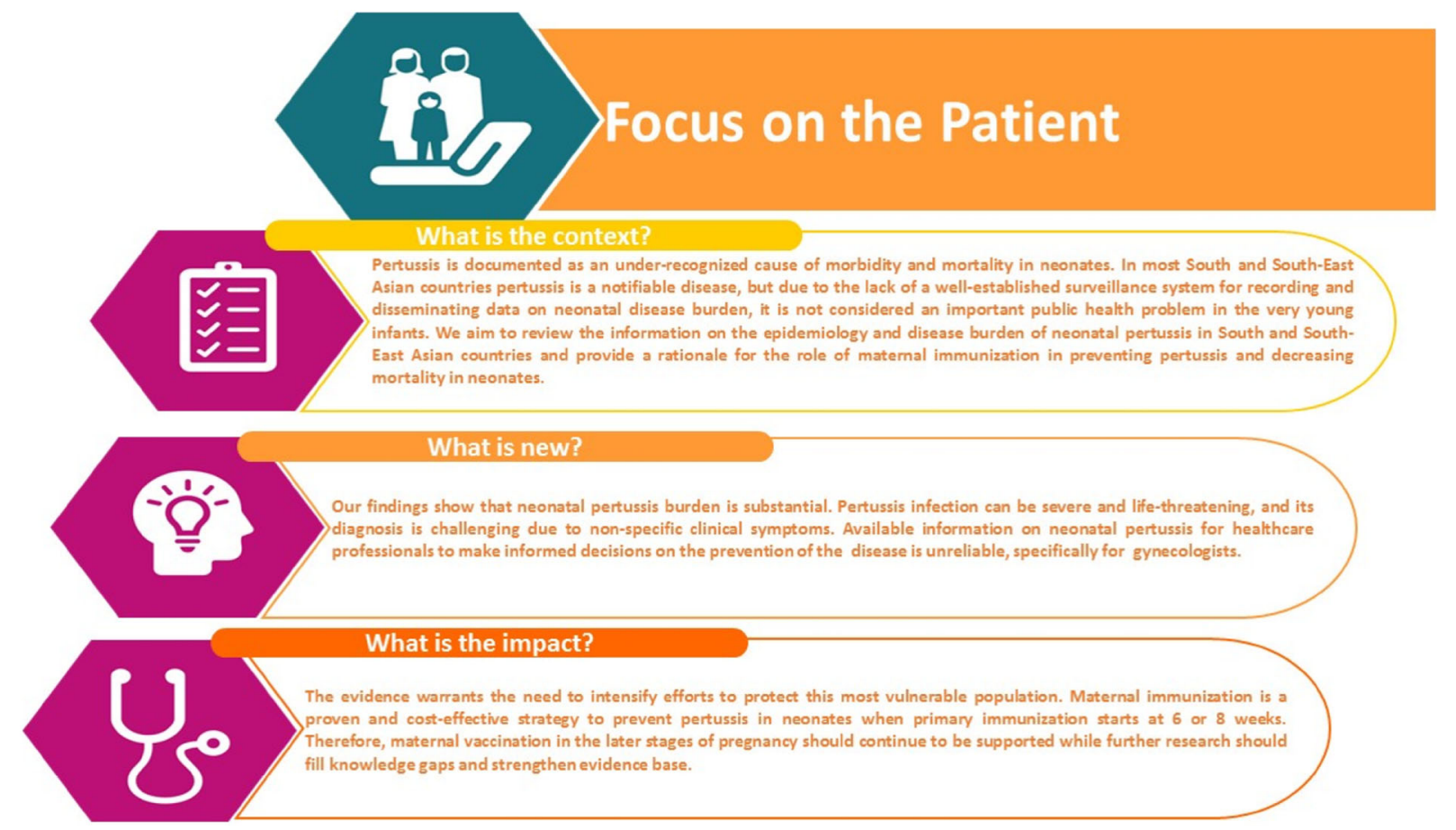

Fig. 1 Plain language summary-focus on the patient. Highlights the context of the article, the importance of neonatal pertussis, maternal immunization and steps that

\section{INTRODUCTION}

Globally, the mortality rate in children $<5$ years of age dropped by $>50 \%$ from 1990 to 2016 (i.e., from 93.2 to 40.5 per 1000 live-births) [1]. The decline in global neonatal mortality was less pronounced compared with the decline in global mortality in children $<5$ years of age. In 2016, 2.6 million newborns died (slightly > 7000 per day on average) before turning 1 month old and accounted for $46 \%$ of all deaths in children $<5$ years of age [1]. In the same year, the regions of sub-Saharan Africa and Asia accounted for $40 \%$ and $38 \%$ of global neonatal mortality. Notably, in South Asia, India accounted for $24 \%$ of global neonatal mortality. Infectious disease and neonatal complications are responsible for the majority of deaths $[2,3]$.

Pertussis, also known as whooping cough, caused by Bordetella pertussis, is a highly contagious, vaccine-preventable respiratory disease causing significant childhood morbidity and mortality [4]. Despite widespread pertussis should be taken in the future to address the impact of neonatal pertussis disease burden

primary immunization in childhood, the pathogen continues to circulate in the population and has even reemerged with increased incidence. The limited ability of vaccines to provide long-term immunity within vaccinated individuals is one of the reasons for this reemergence [5]. Published data report that protection following vaccination wanes after 4-12 years. This situation can pose a significant public health issue as outbreak cycles occur every 3 to 5 years [6]. Importantly, the most vulnerable individuals to pertussis infection are unimmunized or incompletely immunized infants (<6 months of age) [7, 8]. Family members, especially mothers, have been implicated as important sources of pertussis transmission in unprotected infants who are at high risk for complication and death [9].

In most Asian countries including India [10, 11], Korea [12] and the Philippines [13], pertussis is a notifiable disease. However, due to the limited data on neonatal disease burden and the lack of a well-established disease surveillance system, pertussis is not considered an 
important public health issue, especially by local healthcare professionals (HCPs). The HCPs seldom suspect pertussis because of the nonspecificity of symptoms, lack of awareness and non-availability of diagnostic facilities. Together, these factors contribute to gross under-reporting, which leads to an under-representation of the true disease burden $[10,11]$. Data on the neonatal pertussis disease burden across various South and Southeast Asian countries will guide HCPs in making informed decisions about pertussis vaccination to protect newborns. Therefore, the objective of our review was to collate and summarize information on the epidemiology and disease burden of neonatal pertussis in South and Southeast Asian countries (Fig. 1).

\section{METHODS}

A systematic literature review was conducted to identify studies on the epidemiology and burden of neonatal pertussis in South and Southeast Asian countries. This review was conducted according to guidelines in the Cochrane Handbook for Systematic Reviews of Interventions and Preferred Reporting Items for Systematic Literature Reviews and Meta-Analyses (PRISMA) to obtain relevant information using a reproducible, robust and transparent methodology $[14,15]$. In line with these guidelines, we developed a study protocol in which the search strategy and study eligibility criteria were established prior to conducting the review. Afterwards, searches were performed, and retrieved publications were assessed for eligibility based on predefined eligibility criteria. From the final list of publications considered relevant for this review, data were extracted, the scope of which was established a priori. As the final step, we synthesized key findings from the data. The review methodology is detailed below. This article is based on previously conducted studies and does not contain any studies with human participants or animals performed by any of the authors.

\section{Databases and Search Strategy}

We searched the following databases in June 2018: Medline, Embase and the Cochrane Library. Government and regional World Health Organization (WHO) websites were searched for outbreak and epidemic information. Considering the limitation with respect to the breadth of available data, this review also attempted to utilize all publicly available information relevant to the region pertaining to neonatal pertussis disease burden. Additional references were obtained by examination of citations in published reviews.

The following keywords were used in PubMed, Embase and the Cochrane Library: [Pertussis OR Whooping Cough] AND [Newborn OR Infant OR Pediatrics] AND [South Asia OR Bangladesh OR Bhutan OR India OR Nepal OR Pakistan OR Sri Lanka OR Philippines OR Southeast Asia OR Borneo OR Brunei Darussalam OR Cambodia OR Indonesia OR Laos OR Malaysia OR Myanmar OR Singapore OR Thailand OR Vietnam].

Search limitations included restricting to human studies conducted in the above-listed countries. To minimize the introduction of bias, no language limit was applied. We restricted our search to publications after the year 2000. This was done for two reasons: (1) we did not expect to find relevant published epidemiological data on neonatal pertussis before the year 2000. This decision was made based on a preliminary search carried out for the time period before 2000. (2) In the context of healthcare policy and decision-making, recent epidemiological data are considered relevant. Given the time limit applied to our review, case definitions of pertussis in the included studies were either clinically or laboratory confirmed, according to the WHO criteria [16].

\section{Eligibility Criteria and Screening of Articles}

After performing the searches, we screened the identified publications based on the eligibility criteria in two phases: (1) screening of titles and 
Table 1 Inclusion and exclusion criteria

\begin{tabular}{|c|c|c|}
\hline & Inclusion criteria & Exclusion criteria \\
\hline Population & $\begin{array}{l}\text { Newborns ( }<28 \text { days old }) \\
\text { Infants and young children }(<5 \text { years }) \\
\text { Studies in humans only }\end{array}$ & $\begin{array}{l}\text { Population other than that specified in } \\
\text { the inclusion criteria }\end{array}$ \\
\hline Intervention & $\begin{array}{l}\text { Any published journal articles that report pertussis deaths or } \\
\text { mortality rate }\end{array}$ & None \\
\hline Outcome & $\begin{array}{l}\text { Number of cases } \\
\text { Incidence } \\
\text { Age-specific estimates } \\
\text { Hospitalizations } \\
\text { ICU } \\
\text { Deaths } \\
\text { Length of stay (LoS and ICU) }\end{array}$ & $\begin{array}{l}\text { Outcomes other than those covering } \\
\text { epidemiology and burden of disease }\end{array}$ \\
\hline Study design & Quantitative and qualitative studies & $\begin{array}{l}\text { Meta-analysis } \\
\text { Letter to editor } \\
\text { Newspaper } \\
\text { Editorial } \\
\text { Comment } \\
\text { Opinion paper } \\
\text { Reviews }^{\mathrm{a}}\end{array}$ \\
\hline Time limit & 2000 onwards & Before 2000 \\
\hline Language & All languages & None \\
\hline $\begin{array}{l}\text { Geographic } \\
\text { scope }\end{array}$ & $\begin{array}{l}\text { Hong Kong, Bangladesh, Bhutan, India, Nepal, Pakistan, Sri } \\
\text { Lanka, the Philippines, Borneo, Brunei Darussalam, Cambodia, } \\
\text { Indonesia, Laos, Malaysia, Myanmar, Singapore, Thailand and } \\
\text { Vietnam }\end{array}$ & $\begin{array}{l}\text { Areas other than those specified in the } \\
\text { inclusion criteria }\end{array}$ \\
\hline
\end{tabular}

$I C U$ intensive care unit, $L o S$ length of stay

a Reference lists were scanned to identify original articles

abstracts; (2) reviewing of the full-text publications (Table 1).

In view of the low volume of literature expected for neonates in this region, identified publications were included if any information on the pertussis disease burden in the region was reported. References of identified reviews relevant to the topic were screened to identify potentially relevant studies. Articles considered equivocal for inclusion were rescreened by other authors.

\section{Data Extraction and Reporting}

We extracted data using a standardized data extraction sheet, which included information about the study setting, time, vaccination 
history, source of pertussis (exposure), agespecific incidence, prevalence, death and burden of disease [hospitalization, intensive care, length of stay (LoS), etc.]. Information was also collected to understand the various challenges with respect to assessing the disease burden and status of pertussis immunization in South and Southeast Asian countries.

\section{RESULTS}

Our electronic search identified 1235 articles (July 2018), of which we screened 31 full-text publications. In total, ten articles were included in our review (Fig. 2).

\section{Neonatal Pertussis Disease Burden in South and Southeast Asian Countries}

Ten articles from South and Southeast Asian countries reported information on the neonatal pertussis disease burden: Indonesia $(n=1)$ [17]; India $(n=1)$ [18]; Nepal $(n=2)[19,20]$; Pakistan $(n=1)$ [21]; the Philippines $(n=3)$ $[13,22,23]$ and Singapore $(n=2)[24,25]$. These publications sourced information primarily from surveillance data and were conducted either prospectively or retrospectively (Table 2 ).

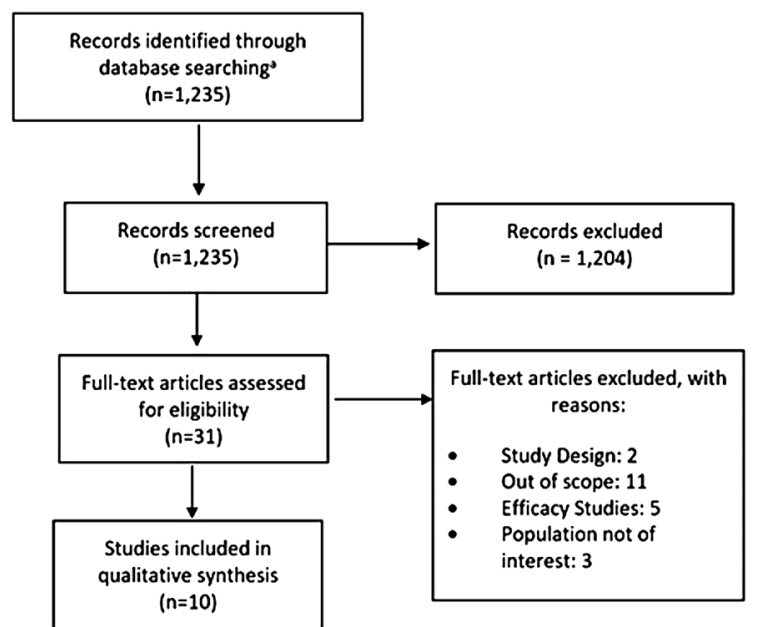

Fig. 2 PRISMA flow diagram. PRISMA: Preferred Reporting Items for Systematic Literature Reviews and Meta-Analyses. ${ }^{a}$ Embase, PubMed, Cochrane Library, Google Scholar

\section{Pertussis Disease Burden}

In Indonesia, an increase in the number of pertussis cases was noted since 2012 (detection by physical examination and Bordet Gengou culture); the majority ( $79 \% ; n=50)$ of the cases were reported in infants aged 0-5 months [17]. Similar findings based on physical symptoms were documented in 2007 during a large pertussis outbreak in India with high rates of suspected pertussis in infants aged $0-1$ year $(71 \%$; $n=39$ ) [18]. In contrast, during 2011-2014, in Nepal, the incidence of polymerase chain reaction (PCR)-confirmed pertussis was 13.3 cases per 1000 infant-years. This surveillance was conducted during a period of low pertussis transmission [20]. Notably, in another study from Nepal in which an influenza vaccine was administered in pregnancy, a low level of protection against pertussis was observed in young infants because of the low prevalence of maternal antibodies (detection of four pertussis antigens using enzyme-linked immunosorbent assays) [19]. Elevated levels of maternal antibodies to pertussis antigens, suggestive of recent pertussis infection, were indeed only found in $4 \%$ of the total $(n=305)$ paired maternal-infant blood samples analyzed [19].

In Pakistan, during 2015-2016, the incidence of pertussis in infants aged $<10$ weeks based on symptoms and PCR test was 3.96 cases per 1000 infants [21]. In the Philippines, despite $87 \%$ pertussis vaccination coverage, an increase in the number of pertussis cases was reported (detection based on physical examination, microbiologic investigations and PCR analyses), especially in infants $<6$ months of age (2012-2013; $n=28)$. Of these, $92.9 \% \quad(n=26)$ were reported in infants aged 0-3 months who had exposure to household members with respiratory symptoms and unknown pertussis vaccination status. Two cases of pertussis were documented in infants $<1$ month of age [22]. An observational study (2012-2015) in the Philippines with children (8 days-13 years) hospitalized with pneumonia showed that $2.9 \%$ $(n=34)$ were PCR-confirmed pertussis cases, and a majority $(65 \%, n=22)$ of these cases were reported in infants $<3$ months old [23]. Another study in the Philippines reported 60\% 
Table 2 Pertussis disease burden in Asia

\begin{tabular}{|c|c|c|c|c|c|c|}
\hline \multirow[t]{2}{*}{ Country } & \multirow[t]{2}{*}{ Study design } & \multirow[t]{2}{*}{ Year } & \multirow[t]{2}{*}{$\begin{array}{l}\text { Number of } \\
\text { cases }\end{array}$} & \multicolumn{2}{|c|}{$\begin{array}{l}\text { Age-specific case } \\
\text { distribution }\end{array}$} & \multirow[t]{2}{*}{$\begin{array}{l}\text { Deaths, } \\
n\end{array}$} \\
\hline & & & & Age & $n(\%)$ & \\
\hline \multirow[t]{2}{*}{ Indonesia } & \multirow{2}{*}{$\begin{array}{l}\text { Retrospective } \\
\text { observational study [17] }\end{array}$} & \multirow{2}{*}{$\begin{array}{l}\text { October } \\
2008-\text { December } \\
2014\end{array}$} & Probable $=61$ & $\leq 6$ Months & $50(79.36)$ & \multirow[t]{2}{*}{0} \\
\hline & & & Confirmed $=2$ & $>6$ Months & $13(20.64)$ & \\
\hline \multirow[t]{2}{*}{ India } & \multirow{2}{*}{$\begin{array}{l}\text { Outbreak investigation } \\
\text { [18] }\end{array}$} & \multirow[t]{2}{*}{2007} & \multirow[t]{2}{*}{98} & $0-1$ Year & $39(39.80)$ & 15 \\
\hline & & & & $2-5$ Years & $59(60.20 \%)$ & 11 \\
\hline Nepal & $\begin{array}{l}\text { Randomized controlled } \\
\text { trial }[20]\end{array}$ & $\begin{array}{l}\text { May 2011-August } \\
2014\end{array}$ & 17 & $\leq 6$ Months & $17(100)$ & 0 \\
\hline Pakistan & $\begin{array}{l}\text { Community-based } \\
\text { prospective surveillance } \\
{[21]}\end{array}$ & $\begin{array}{l}\text { February } \\
2015-\text { April, } \\
2016\end{array}$ & 8 & $\leq 10$ Weeks & $8(100)$ & 1 \\
\hline \multirow{6}{*}{$\begin{array}{l}\text { The } \\
\text { Philippines }\end{array}$} & \multirow[t]{3}{*}{ Retrospective study [22] } & \multirow{3}{*}{$\begin{array}{l}\text { December } \\
2012 \text {-August, } \\
2013\end{array}$} & \multirow[t]{3}{*}{28} & $<1$ Months & $2(7.14)$ & \multirow[t]{3}{*}{13} \\
\hline & & & & 1-3 Months & $24(85.71)$ & \\
\hline & & & & 4-6 Months & $1(3.57)$ & \\
\hline & Trends [13] & $\begin{array}{l}\text { January-June } \\
2016\end{array}$ & 143 & $<1$ Year & $60(41.96)$ & 8 \\
\hline & \multirow[t]{2}{*}{ Observational study [23] } & August & \multirow[t]{2}{*}{34} & $<3$ Months & $22(64.71)$ & \multirow[t]{2}{*}{5} \\
\hline & & $\begin{array}{l}\text { 2012-February, } \\
2015\end{array}$ & & $>3$ Months & $12(35.29)$ & \\
\hline \multirow[t]{4}{*}{ Singapore } & \multirow[t]{2}{*}{ Retrospective review [24] } & \multirow[t]{2}{*}{$2004-2007$} & \multirow[t]{2}{*}{45} & $<6$ Months & $31(68.89)^{\mathrm{a}}$ & \multirow[t]{2}{*}{0} \\
\hline & & & & $<1$ year & $1(2.22)$ & \\
\hline & \multirow[t]{2}{*}{ Retrospective review [25] } & \multirow[t]{2}{*}{$2007-2016$} & \multirow[t]{2}{*}{200} & $\leq 3$ Months & $122(61)$ & \multirow[t]{2}{*}{2} \\
\hline & & & & $>3$ Months & $88(44)$ & \\
\hline
\end{tabular}

Among which number of ICU admissions: $a=3$

$I C U$ intensive care unit, $n r$ not reported

higher pertussis cases $(n=143)$ in the first half of 2016 compared with the previous year, of which $81.1 \%$ of cases were documented in infants $<1$ year of age [13]. A study (2004-2007) in Singapore recorded 45 pertussis cases (detection based on microbiological investigations and PCR analyses), mostly in infants $<6$ months of age [24]. Two hundred PCR-confirmed pertussis cases (median age: 2.75 months) were reported over 10 years (2007-2016) in Singapore; 61\% of cases were reported in infants $<3$ months old [25].

\section{Clinical Presentation and Laboratory Findings}

The most common symptoms a pertussis patient presents are cough with or without paroxysms, cyanosis, apnea, tachypnea, difficulty in breathing and leukocytosis. In a study from the Philippines, pertussis patients $(n=28$, one patient $>1$ year of age) presented with paroxysms of cough (100\%), accompanied by cyanosis (100\%) and tachypnea (93\%). The characteristic whoop was not seen in any of the 
patients. All patients had leukocytosis (mean WBC: $\left.56.14 \times 10^{9} / 1\right)$, lymphocytic predominance and thrombocytosis (i.e., mean platelet count: $567 \times 10^{9} / 1$ ) [22]. In another study from Nepal, the most common symptoms were cough and difficulty in breathing [20]. Similar symptoms were noted in a study from the Philippines, along with central cyanosis [23]. In a retrospective study from Singapore, most of the pertussis infections were seen in infants < 6 months; cough, apnea, cyanosis, fever and requirement of oxygen for recurrent desaturations were noted [24].

\section{Complications, Intensive Care Unit (ICU) Admission and Length of Stay}

Pertussis can cause high complication rates, especially in infants who are too young to be vaccinated. In a study from the Philippines, the most common complications were pneumonia requiring mechanical ventilation $(64 \%)$, acute respiratory distress syndrome (ARDS) (28\%), seizures $(21 \%)$, nosocomial pneumonia $(11 \%)$ and myocarditis (11\%). The length of hospital stay was 7.4 days on average [22]. In another study from Singapore, children $<6$ months of age had severe disease, and the length of hospital stay was 5.1 days, compared with 3.5 days in $>6$ month olds [24]. Furthermore, in a retrospective review of pertussis admissions from Singapore (2007-2016), risk factors associated with ICU admission comprised: age $<3$ months, positive contact history, underlying comorbidity, prematurity, absence of diphtheria-tetanus-acellular pertussis (DTaP) vaccination, lymphocytosis, hyperleukocytosis, thrombocytosis and pneumonia [25].

\section{Mortality}

A large pertussis outbreak in India led to 15 deaths of infants $<1$ year of age [18]. In a study in Pakistan, one death was reported among pertussis-positive cases [21]. In a retrospective chart review study in the Philippines, the case fatality rate in the series was $46 \%(n=13)$, and the median age of mortality was 7 weeks (range 4 to 12 weeks). Eleven patients (85\%) did not receive diphtheria, pertussis and tetanus (DPT) vaccination, and six of them were not eligible. All mortality cases had leukocytosis with lymphocytic predominance and thrombocytosis [22]. Similarly, in another study in the Philippines, a higher case fatality ratio among 34 pertussis-positive cases $(14.7 \% ; n=5)$ was observed compared with 102 pertussis-negative cases $(1.0 \% ; n=1)$; all five deaths were reported in infants $<6$ months of age [23]. Similar findings were documented in another study reporting a case fatality rate of $5.59 \%(n=143)$ [13].

\section{Challenges in Estimating Pertussis Disease Burden}

Establishing accurate pertussis incidence in this region is difficult and is influenced by several factors, the reasons for which are further examined. We found a few studies providing some data on the neonatal pertussis disease burden in South and Southeast Asia (Table 2). Importantly, most of the data were obtained from hospital-based retrospective studies describing a series of pertussis cases that do not give actual incidence. Official statistics were difficult to obtain for most countries as mandatory pertussis surveillance systems based on active reporting are not well established in the region. Existing surveillance systems in the region rely on passive reporting where most cases are known to go unreported [26]. However, even in countries where disease reporting is mandatory, the pertussis burden may be underestimated. This is because the diagnosis of pertussis is challenging, especially in neonates, as other respiratory pathogens cause pertussislike illnesses and the clinical presentation of pertussis varies. The situation is further complicated by the fact that case definitions for pertussis vary across countries [27] (refer to Table 3 for an overview of case definitions for the different age groups used for pertussis). Moreover, specific guidelines for the diagnosis of neonatal pertussis are not yet available, and existing recommendations are targeted at older children. In addition, most neonatal deaths occur outside the hospital environment; 
Table 3 Algorithm for the diagnosis of pertussis and clinical case definition of pertussis for surveillance purposes

\begin{tabular}{|c|c|c|c|}
\hline \multirow[t]{2}{*}{ Age groups } & \multicolumn{2}{|c|}{ Algorithm for the diagnosis of pertussis } & \multirow{2}{*}{$\begin{array}{l}\text { Clinical case definition of } \\
\text { pertussis for surveillance } \\
\text { purposes } \\
\text { Cough illness in a person } \\
\text { with no or minimal fever }\end{array}$} \\
\hline & Clinical capabilities only & Access to laboratory facilities & \\
\hline $0-3$ months & $\begin{array}{l}\text { Cough of any duration which } \\
\text { is not improving (seen as } \\
\text { paroxysmal or not) } \\
\text { Coryza (not becoming } \\
\text { purulent) } \\
\text { Afebrile/low-grade fever } \\
\text { Cough and apnea } \\
\text { Cough and seizures } \\
\text { Cough and cyanosis } \\
\text { Cough and emesis } \\
\text { Pneumonia } \\
\text { Co-infection with RSV or } \\
\text { adenovirus potentially leading } \\
\text { to expiratory distress and } \\
\text { fever }\end{array}$ & $\begin{array}{l}\text { Early stage (cough is }<3 \text { weeks in } \\
\text { duration) } \\
\text { Increased WBC ( } \geq 20,000 \\
\text { with } \geq 10,000 \text { lymphocytes) } \\
\text { PCR and culture }{ }^{\mathrm{a}} \\
\text { Late stage (cough is }>3 \text { weeks in } \\
\text { duration) } \\
\text { PCR and culture }{ }^{\mathrm{b}, \mathrm{c}}\end{array}$ & $\begin{array}{l}\text { Cough and coryza with no or } \\
\text { minimal fever PLUS: } \\
\text { Whoop OR } \\
\text { Apnea OR } \\
\text { Posttussive emesis OR } \\
\text { Cyanosis OR } \\
\text { Seizure } \\
\text { Pneumonia } \\
\text { Close exposure to an adolescent } \\
\text { or adult (usually a family } \\
\text { member) with a prolonged } \\
\text { afebrile cough illness }\end{array}$ \\
\hline 4 months -9 years & $\begin{array}{l}\text { Paroxysmal non-productive } \\
\text { cough of } 7 \text { days duration or } \\
\text { more } \\
\text { Coryza (not becoming } \\
\text { purulent) } \\
\text { Afebrile/low-grade fever } \\
\text { Whoop } \\
\text { Apnea } \\
\text { Posttussive emesis } \\
\text { Subconjunctival hemorrhage } \\
\text { Cyanosis } \\
\text { Sleep disturbance }\end{array}$ & $\begin{array}{l}\text { Early stage (cough is }<3 \text { weeks in } \\
\text { duration) } \\
\text { PCR } \\
\text { Serology (IgG-PT), if } \geq 1 \text { year } \\
\text { after pertussis vaccination } \\
\text { Late stage (cough is }>3 \text { weeks in } \\
\text { duration) } \\
\text { Serology (IgG-PT), if } \geq 1 \text { year } \\
\text { after pertussis vaccination }\end{array}$ & $\begin{array}{l}\text { Paroxysmal cough with no or } \\
\text { minimal fever PLUS: } \\
\text { Whoop OR } \\
\text { Apnea OR } \\
\text { Posttussive emesis } \\
\text { Seizure } \\
\text { Worsening of symptoms at } \\
\text { night } \\
\text { Pneumonia } \\
\text { Close exposure to an adolescent } \\
\text { or adult (usually a family } \\
\text { member) with a prolonged } \\
\text { afebrile cough illness }\end{array}$ \\
\hline
\end{tabular}


Table 3 continued

\begin{tabular}{|c|c|c|c|}
\hline \multirow[t]{2}{*}{ Age groups } & \multicolumn{2}{|c|}{ Algorithm for the diagnosis of pertussis } & \multirow{2}{*}{$\begin{array}{l}\text { Clinical case definition of } \\
\text { pertussis for surveillance } \\
\text { purposes } \\
\text { Cough illness in a person } \\
\text { with no or minimal fever }\end{array}$} \\
\hline & Clinical capabilities only & Access to laboratory facilities & \\
\hline \multirow[t]{9}{*}{$\geq 10$ years } & $\begin{array}{l}\text { Paroxysmal non-productive } \\
\text { cough of } 7 \text { days duration or } \\
\text { more }\end{array}$ & $\begin{array}{l}\text { Early stage (cough is }<3 \text { weeks in } \\
\text { duration) } \\
\text { PCR }\end{array}$ & $\begin{array}{l}\text { Non-productive paroxysmal } \\
\text { cough } \geq 2 \text { weeks duration } \\
\text { without fever PLUS: }\end{array}$ \\
\hline & $\begin{array}{l}\text { Coryza (not becoming } \\
\text { purulent) }\end{array}$ & $\begin{array}{l}\text { Serology (IgG-PT), if } \geq 1 \text { year } \\
\text { after pertussis vaccination }\end{array}$ & $\begin{array}{l}\text { Whoop OR } \\
\text { Apnea OR }\end{array}$ \\
\hline & $\begin{array}{l}\text { Afebrile/low-grade fever } \\
\text { Whoop }\end{array}$ & $\begin{array}{l}\text { Late stage (cough is }>3 \text { weeks in } \\
\text { duration) }\end{array}$ & $\begin{array}{l}\text { Sweating episodes between } \\
\text { paroxysms }\end{array}$ \\
\hline & Apnea & Serology (IgG-PT), if $\geq 1$ year & Posttussive emesis \\
\hline & Posttussive emesis & after pertussis vaccination & Worsening of symptoms at \\
\hline & Subconjunctival hemorrhage & & night \\
\hline & Cyanosis & & \\
\hline & Sleep disturbance & & \\
\hline & $\begin{array}{l}\text { Sweating episodes between } \\
\text { paroxysms }\end{array}$ & & \\
\hline
\end{tabular}

$\overline{I g G \text { immunoglobulin } \mathrm{G}, P C R \text { polymerase chain reaction, } P T \text { pertussis toxin, } R S V \text { respiratory syncytial virus, } W B C \text { white }}$ blood cell

${ }^{a}$ In areas where PCR is not available, samples may be sent for culture confirmation to reference laboratories

b False negatives are possible

c Serology not informative in this age cohort

Source: Adapted from Cherry et al. [63]

therefore, it is also difficult to ascertain and report the true causes of neonatal deaths.

Accurate laboratory identification of $B$. pertussis remains problematic [28-31]. Clinically accurate laboratory diagnostic tests are essential for the confirmation of pertussis and can be done via culture, direct-fluorescent-antibody testing, serology and PCR. Although PCR is a robust detection method, assays are expensive, and this technique has usually been unavailable on a routine basis in Asia. Factors such as the widespread availability of antibiotics and initiation of treatment prior to sample collection contribute to the increasing number of negative cultures and further hampers disease detection $[7,26]$. These specific issues are compounded in the case of neonates.

\section{Current Scenario of Pertussis Vaccination}

Until the 1990s, pertussis control was mainly carried out via a vaccination calendar consisting of a three-dose primary series. Under this scheme, the first dose was administered as early as 6 weeks of age, and subsequent doses were provided within 6 months [32]. While coverage has improved, many countries have added vaccination boosters beyond the primary doses with the main aim of reducing the high disease burden in the most vulnerable populations. However, recent trends in the resurgence of pertussis across the age groups pose an urgent need to protect newborns [33], especially during the time window between birth and completion of the primary vaccination schedule (please see 
https://doi.org/10.6084/m9.figshare.7951187) [34].

A resurgence in pertussis disease has led to a shift in primary pertussis prevention that has relied on infant immunization to protection by cocooning, i.e., vaccination of close contacts of newborn infants (new mothers, fathers, grandparents, siblings, caretakers, etc.), thereby reducing the risk of pertussis exposure for newborns. Cocooning programs, though effective, have had limited success and are not costeffective [35]. Immunization of women during pregnancy rather than during the immediate postpartum period (the initial cocooning recommendation) is a better approach by directly providing protection through transplacental transfer of maternal vaccine-induced antibodies $[35,36]$. Evidence from clinical trials and preliminary surveillance data suggests that maternal vaccination is well tolerated in pregnant women, fetuses and newborns and is effective in protecting the latter against pertussis [37-40]. While immunization during pregnancy offers several benefits, few studies have shown that maternally derived immunoglobulin $G$ antibodies cause blunting of the infant antibody responses for the same or related antigens after primary vaccination $[41,42]$. The clinical relevance of blunting is not apparent, and further investigation of blunting on pregnant women and infants is required [39].

In 2011, the Tdap (reduced antigen quantity) vaccine was recommended in unvaccinated pregnant women by the US Advisory Committee on Immunization Practice (ACIP) [35]. The WHO recommended that national programs consider the vaccination of pregnant women with one dose of Tdap (in the second or third trimester, preferably at least 15 days before the end of pregnancy) when infant morbidity or mortality from pertussis is high or increasing [32]. Pertussis vaccination practices differ across the Asia-Pacific region, with only some countries recommending booster dosing. Countries usually adapt their recommendations from the WHO based on local information about risk groups, disease burden and cost-effectiveness, but these data are limited in low- or middleincome countries [26].

\section{DISCUSSION}

Our study shows that the majority of reported pertussis cases involve neonates and young infants. An increase in the number of pertussis cases has been noted since early 2000 ranging from 61 to $92.9 \%$ in infants $0-3$ months old. The most common symptoms an infant is likely to present with are cough with or without paroxysms, cyanosis, apnea, tachypnea, difficulty in breathing and leukocytosis. In addition, it can lead to hospitalization (length of stay: 5-7 days), complications (e.g., pneumonia, seizures) and mortality ranging from 5.6 to $14.7 \%$.

A resurgence of pertussis across age groups has occurred in several countries in recent years, specifically in unimmunized (0-8 weeks) or partially immunized (2-6 months) infants [43-45]. Neonates also have significantly higher rates of complications and death compared with other age groups, which is in line with previous reports [44-47]. During 1980-2016, in countries such as Australia, Belgium, Brazil, Portugal, the UK and the US where high coverage levels of pertussis vaccination have been reported, a rise in the incidence of pertussis has been observed [37, 46, 48-51]. Considering this situation in well-developed countries, the pertussis burden is likely to be much higher in lowand middle-income countries [26]. While data from 2008 show that there were 148,095 reported cases globally [52], the WHO estimated that there were 16 million cases of pertussis globally, of which 95\% were in developing countries in the same year [53]. In India, the average number of cases reported per year between 2000 and 2016 is $>30,000$, which is far below estimates [54].

Maternal immunization is known to protect neonates from pertussis until they are old enough to receive the primary vaccination series [37]. To reduce the pertussis burden in infants, the WHO considers maternal immunization to be a cost-effective strategy, in addition to cocooning, and recommends its use in countries with high pertussis morbidity and mortality in infants too young to be vaccinated [32]. In addition to the ACIP, the American College of Obstetricians and Gynecologists [55], 
the Royal College of Obstetricians and Gynecologists [56] and national bodies such as the Indian Academy of Pediatrics [57] and the Federation of Obstetrics and Gynecological Societies of India [58] have also recommended the use of Tdap during each pregnancy. Despite national recommendations in several countries, in this region, uptake in pregnant women remains variable [26]. Multiple strategies to increase vaccine uptake should be considered to increase protection in infants, such as dissemination of information and education about the disease and the need for prevention in this vulnerable population $[51,59,60]$. A study reported that in Korea $95.1 \%$ of women surveyed received information from doctors about Tdap vaccination and that $81.2 \%$ of them were not aware of the need for vaccination. Most importantly, $89.6 \%$ considered the recommendation of obstetric doctors as the most influencing factor regarding their decision for Tdap vaccination [59]. This review intends to raise awareness among HCPs on the existence of neonatal pertussis in individual Asian countries and the need to improve Tdap vaccination coverage among pregnant women. Remarkably, obstetricians and gynecologists played a significant role in the elimination of maternal and neonatal tetanus in India $[61,62]$.

We recognize there are some limitations to this work. Studies included in this review did not specifically report on the actual incidence of pertussis. Indeed, we did not conduct screening activities with two independent reviewers and did not perform a risk-of-bias analysis for the publications included in this study. As we aimed to obtain a better understanding of published epidemiology and disease burden data, having one researcher conducting screening activity was appropriate and a risk-of-bias analysis was not necessary. We understand that the geographic scope of the review is limited.

\section{CONCLUSION}

There is a paucity of data on the neonatal pertussis disease burden in the region of South and Southeast Asia. Our findings indicate that there is a significant percentage of reported cases of pertussis in neonates and that the disease can be severe and life-threatening. Outbreaks are common in Asia and across the rest of the world and reemerge every 3 to 5 years. Thus, there is a need to intensify efforts to protect this most vulnerable population. Maternal immunization is a proven and cost-effective strategy to prevent pertussis in neonates when primary immunization starts at 6 or 8 weeks, as recommended by the WHO. Therefore, maternal vaccination should continue to be supported, while further research should fill knowledge gaps and a robust public health surveillance program for pertussis must be implemented to better understand the disease burden and to monitor the impact of the vaccine among infants and pregnant women.

\section{ACKNOWLEDGEMENTS}

Funding. GlaxoSmithKline Biologicals SA funded this review and all costs associated with its development and publication. All authors had full access to all of the data in this study and take complete responsibility for the integrity of the data and accuracy of the data analysis.

Authorship. All named authors meet the International Committee of Medical Journal Editors (ICMJE) criteria for authorship for this article, take responsibility for the integrity of the work as a whole, and have given their approval for this version to be published.

Medical Writing, Editorial and Other Assistance. The authors would like to thank Miguel Hernan Vicco and Maria Angeles Ceregido for their careful revision of the manuscript, and the Business \& Decision Life Sciences platform for editorial assistance and manuscript coordination, on behalf of GSK. Benjamin Lemaire coordinated the manuscript development and editorial support. Amrita Ostawal (Arete Communication UG, Berlin, Germany) provided medical writing support. Editorial support and medical writing assistance were funded by GlaxoSmithKline Biologicals SA. 
Disclosures. Ashish Agrawal is an employee of the GSK group of companies. Sanjeev Singh is an employee of the GSK group of companies. Walid Kandeil is an employee of the GSK group of companies. Shafi Kolhapure is an employee of the GSK group of companies. Rishma Pai and Tanu Singhal have nothing to disclose.

Compliance with Ethics Guidelines. This article is based on previously conducted studies and does not contain any studies with human participants or animals performed by any of the authors.

Data Availability. The datasets generated during and/or analyzed during the current study are available from the corresponding author on reasonable request.

Open Access. This article is distributed under the terms of the Creative Commons Attribution-NonCommercial 4.0 International License (http://creativecommons.org/licenses/ by-nc/4.0/), which permits any noncommercial use, distribution, and reproduction in any medium, provided you give appropriate credit to the original author(s) and the source, provide a link to the Creative Commons license, and indicate if changes were made.

\section{REFERENCES}

1. UNICEF. Under-five mortality. 2018. https://data. unicef.org/topic/child-survival/under-fivemortality/. Accessed 6 Aug-2018.

2. Every child alive: The urgent need to end newborn deaths. United Nations Children's Fund (UNICEF). 2018. https://data.unicef.org/wp-content/uploads/ 2018/02/Every-Child-Alive-report_FINAL-1.pdf. Accessed 12 June 2018.

3. Levels and Trends in Child Mortality. Estimates Developed by the UN Inter-agency Group for Child Mortality Estimation, United Nations Children's Fund, New York, United Nations Inter-agency Group for Child Mortality Estimation (UN IGME). 2017. https://www.childmortality.org/files_v21/ download/IGME\%20report\%202017\%20child\% 20mortality\%20final.pdf. Accessed 12 June 2018.
4. Centers for Disease Control and Prevention. Epidemiology and Prevention of VaccinePreventable Diseases. Hamborsky J, Kroger A, Wolfe S, eds. 13th ed. Supplement. Washington D.C. Public Health Foundation, 2017. Available at. https://www.cdc.gov/vaccines/pubs/pinkbook/ downloads/supplement.pdf. Accessed July 2018.

5. Moraga-Llop FA, Campins-Marti M. Pertussis vaccine. Reemergence of the disease and new vaccination strategies. Enferm Infecc Microbiol Clin. 2015;33:190-6.

6. Wendelboe AM, Van Rie A, Salmaso S, Englund JA. Duration of immunity against pertussis after natural infection or vaccination. Pediatr Infect Dis J. 2005;24:S58-61.

7. Rocha G, Soares P, Soares H, Pissarra S, Guimaraes $H$. Pertussis in the newborn: certainties and uncertainties in 2014. Paediatr Respir Rev. 2015;16:112-8.

8. von Koenig CHW, Guiso N. Global burden of pertussis: signs of hope but need for accurate data. Lancet Infect Dis. 2017;17:889-90.

9. Cherry JD. Pertussis in young infants throughout the world. Clin Infect Dis. 2016;63:S119-S12222.

10. Chitkara AJ, Kukreja S, Shah RC. Pertussis and diphtheria immunization. Indian Pediatr. 2008;45:723-7.

11. Murthy S, Godinho MA, Lakiang T, Lewis MGG, Lewis L, Nair NS. Efficacy and safety of pertussis vaccination in pregnanacy to prevent whooping cough in early infancy. Cochrane Database Syst Rev. 2018;4:CD013008. https://doi.org/10.1002/ 14651858.CD013008.

12. Park S, Cho E. National Infectious Diseases Surveillance data of South Korea. Epidemiol Health. 2014;36:e2014030.

13. Pertussis Cases. Department of Health. Republic of the Philippines. 2016. https://www.doh.gov.ph/ sites/default/files/statistics/PERTUSSIS\%20MW25. pdf. Accessed 22 July 2018.

14. Moher D, Liberati A, Tetzlaff J, Altman DG. Preferred reporting items for systematic reviews and meta-analyses: the PRISMA statement. PLoS Med. 2009;6:e1000097.

15. Julian PT Higgins and Sally Green. Cochrane Handbook for Systematic Reviews of Interventions Version 5.1.0. The Cochrane Collaboration, 2011. http://handbook-5-1.cochrane.org/. Accessed June 2018. 
16. World Health Organization. WHO-recommended surveillance standard of pertussis. https://www. who.int/immunization/monitoring_surveillance/ burden/vpd/surveillance_type/passive/pertussis_ standards/en/. Accessed 15 Oct 2018.

17. Nataprawira HM, Phangkawira E. A retrospective study of acute pertussis in Hasan Sadikin HospitalIndonesia. J Acute Dis. 2015;4:147-51.

18. Takum T, Gara D, Tagyung H, Murhekar MV. An outbreak of pertussis in Sarli Circle of Kurungkumey district, Arunachal Pradesh. India. Indian Pediatr. 2009;46:1017-20.

19. Hughes MM, Englund JA, Edwards K, Yoder S, Tielsch JM, Steinhoff M, et al. Pertussis seroepidemiology in women and their infants in Sarlahi District. Nepal. Vaccine. 2017;35:6766-73.

20. Hughes MM, Englund JA, Kuypers J, Tielsch JM, Khatry SK, Shrestha L, et al. Population-based pertussis incidence and risk factors in infants less than 6 months in Nepal. J Pediatric Infect Dis Soc. 2017;6:33-9.

21. Omer SB, Kazi AM, Bednarczyk RA, Allen KE, Quinn $\mathrm{CP}$, Aziz F, et al. Epidemiology of pertussis among young pakistani infants: a community-based prospective surveillance study. Clin Infect Dis. 2016;63:S148-S153153.

22. Bonus R, delos Reyes C, Dy C, Ramos R. Clinical profile of pertussis among pediatric patients admitted at the Philippine General Hospital. Pediatric Infectious Disease Society of the Philippines, vol 16, pp 21-27. 2015. https://www.pidsphil.org/ journal_summary.php?id=192. Accessed 22 July 2018.

23. Sadiasa A, Saito-Obata M, Dapat C. Bordetella pertussis infection in children with severe pneumonia, Philippines, 2012-2015. Vaccine. 2017;35:993-6.

24. Goh A, Chong CY, Tee N, Loo LH, Yeo JG, Chan YH. Pertussis-an under-diagnosed disease with high morbidity in Singapore children. Vaccine. 2011;29:2503-7.

25. Chong CY, Yung CF, Tan NW, Acharyya S, Thoon KC. Risk factors of ICU or high dependency requirements amongst hospitalized pediatric pertussis cases: A 10 year retrospective series Singapore. Vaccine. 2017;35:6422-8.

26. Forsyth $\mathrm{K}$, Thisyakorn $\mathrm{U}$, von Konig $\mathrm{CH}$, Tan $\mathrm{T}$, Plotkin S. Pertussis control in the Asia-Pacific region: a report from the Global Pertussis Initiative. Southeast Asian J Trop Med Public Health. 2012;43:699-711.
27. Cherry JD, Grimprel E, Guiso N, Heininger U, Mertsola J. Defining pertussis epidemiology: clinical, microbiologic and serologic perspectives. Pediatr Infect Dis J. 2005;24:S25-34.

28. Frumkin K. Pertussis and persistent cough: practical, clinical and epidemiologic issues. J Emerg Med. 2013;44:889-95.

29. Wirsing von Konig CH. Pertussis diagnostics: overview and impact of immunization. Expert Rev Vaccines. 2014;13:1167-74.

30. Riffelmann M, Mohr J, Hellenbrand W, Wirsing von Koenig $\mathrm{CH}$. Time since last vaccine dose in PCRpositive and PCR-negative children with suspected pertussis to monitor pertussis vaccine effectiveness. Eur J Clin Microbiol Infect Dis. 2014;33:805-8.

31. Zouari A, Smaoui H, Kechrid A. The diagnosis of pertussis: which method to choose? Crit Rev Microbiol. 2012;38:111-21.

32. Pertussis vaccines: WHO position paper, August 2015-Recommendations. Vaccine. World Health Organisation. 2016;34:1423-5.

33. Ghotaslou R, Asl Y. Seroepidemiology of pertussis disease in Asia: A literature review. Ann Trop Med Pub Health. 2017;10:1425-31.

34. Jones C, Heath P. Antenatal immunization. Hum Vaccin Immunother. 2014;10:2118-222.

35. Updated recommendations for use of tetanus toxoid. reduced diphtheria toxoid and acellular pertussis vaccine (Tdap) in pregnant women and persons who have or anticipate having close contact with an infant aged \%3c12 months -Advisory Committee on Immunization Practices (ACIP), 2011. MMWR Morb Mortal Wkly Rep. 2011;60:1424-6.

36. Vojtek I, Dieussaert I, Doherty TM, Franck V, Hanssens L, Miller J, et al. Maternal immunization: where are we now and how to move forward? Ann Med. 2018;50:193-208.

37. Sobanjo-Ter Meulen A, Duclos P, McIntyre P, Lewis $\mathrm{KD}$, Van Damme P, O'Brien KL, et al. Assessing the evidence for maternal pertussis immunization: a report from the bill \& melinda gates foundation symposium on pertussis infant disease burden in low- and lower-middle-income countries. Clin Infect Dis. 2016;63:S123-S133133.

38. Gkentzi D, Katsakiori P, Marangos M, Hsia Y, Amirthalingam G, Heath PT, et al. Maternal vaccination against pertussis: a systematic review of the recent literature. Arch Dis Child Fetal Neonatal Ed. 2017;102:F456-F463463. 
39. Cherry JD. Editorial commentary: the effect of Tdap vaccination of pregnant women on the subsequent antibody responses of their infants. Clin Infect Dis. 2015;61:1645-7.

40. Winter K, Cherry JD, Harriman K. Effectiveness of prenatal tetanus, diphtheria, and acellular pertussis vaccination on pertussis severity in infants. Clin Infect Dis. 2017;64:9-14.

41. Ladhani SN, Andrews NJ, Southern J, Jones CE, Amirthalingam G, Waight PA, et al. Antibody responses after primary immunization in infants born to women receiving a pertussis-containing vaccine during pregnancy: single arm observational study with a historical comparator. Clin Infect Dis. 2015;61:1637-44.

42. Maertens K, Cabore RN, Huygen K, Vermeiren S, Hens N, Van Damme P, et al. Pertussis vaccination during pregnancy in Belgium: follow-up of infants until 1 month after the fourth infant pertussis vaccination at 15 months of age. Vaccine. 2016;34:3613-9.

43. Tan T, Dalby T, Forsyth K, Halperin SA, Heininger $U$, Hozbor D, et al. Pertussis across the globe: recent epidemiologic trends from 2000 to 2013. Pediatr Infect Dis J. 2015;34:e222-e23232.

44. Cherry JD, Wendorf K, Bregman B, Lehman D, Nieves D, Bradley JS, et al. An observational study of severe pertussis in 100 infants $\% 3 c /=120$ days of age. Pediatr Infect Dis J. 2018;37:202-5.

45. Winter K, Zipprich J, Harriman K, Murray EL, Gornbein J, Hammer SJ, et al. Risk factors associated with infant deaths from pertussis: a case-control study. Clin Infect Dis. 2015;61:1099-106.

46. Tiwari TSP, Baughman AL, Clark TA. First pertussis vaccine dose and prevention of infant mortality. Pediatrics. 2015;135(6):990-9.

47. Murray EL, Nieves D, Bradley JS, Gargas J, Mason WH, Lehman D, et al. Characteristics of severe bordetella pertussis infection among infants $\leq 90$ days of age admitted to pediatric intensive care units-Southern California, September 2009-June 2011. J Pediatr Infect Dis Soc. 2013;2:1-6.

48. Saul N, Wang K, Bag S, Baldwin H, Alexander K, Chandra $\mathrm{M}$, et al. Effectiveness of maternal pertussis vaccination in preventing infection and disease in infants: the NSW Public Health Network case-control study. Vaccine. 2018;36:1887-922.

49. Domenech de Cellès M, Magpantay FM, King AA, Rohani P. The pertussis enigma: reconciling epidemiology, immunology and evolution. Proc Biol Sci. 2016;283(1822):20152309.
50. Kerr S, Van Bennekom CM, Liang JL, Mitchell AA. Tdap vaccination coverage during pregnancy-selected sites, United States, 2006-2015. MMWR Morb Mortal Wkly Rep. 2017;66:1105-8.

51. Mohammed H, Clarke M, Koehler A, Watson M, Marshall H. Factors associated with uptake of influenza and pertussis vaccines among pregnant women in South Australia. PLOS One. 2018;13:e0197867.

52. World Health Organization. Data, statistics and graphics - Disease incidence time series. 2018. https://apps.who.int/immunization_monitoring/ globalsummary/timeseries/tsincidencepertussis. html. Accessed July 2018.

53. World Health Organization. Immunization, vaccines and biological-pertussis. 2018. https://www. who.int/immunization/topics/pertussis/en/. Accessed July 2018.

54. WHO vaccine-preventable diseases: monitoring system 2017 global summary. 2018. https://apps. who.int/immunization_monitoring/ globalsummary/timeseries/tsincidencepertussis. html. Accessed 26 Feb 2018.

55. Committee Opinion No. 718: Update on immunization and pregnancy: tetanus, diphtheria, and pertussis vaccination. Obstet Gynecol. 2017;130:e153-e157157.

56. RCOG statement: Pertussis (whooping cough) vaccination now offered from 20 weeks of pregnancy. 2016. https://www.rcog.org.uk/en/news/rcogstatement-pertussis-whooping-cough-vaccinationnow-offered-from-20-weeks-of-pregnancy/. Accessed 6 Aug 2018.

57. Vashishtha VM, Bansal CP, Gupta SG. Pertussis vaccines: position paper of Indian Academy of Pediatrics (IAP). Indian Pediatr. 2013;50:1001-9.

58. Federation of Obstetrics \& Gynaecological Societies of India. Good clinical practice recommendations on preconception care. 2018. https://www.fogsi. org/wp-content/uploads/2016/09/FOGSI-PCCRGuideline-Booklet-Orange.pdf. Accessed 14 Oct 2018.

59. Ko HS, Jo YS, Kim YH, Park Y-G, Wie JH, Cheon J, et al. Knowledge and acceptability about adult pertussis immunization in Korean women of childbearing age. Yonsei Med J. 2015;56:1071-8.

60. Frere J, De Wals P, Ovetchkine P, Coic L, Audibert F, Tapiero B. Evaluation of several approaches to immunize parents of neonates against $\mathrm{B}$. pertussis. Vaccine. 2013;31:6087-91. 
61. Cousins S. India is declared free of maternal and neonatal tetanus. BMJ. 2015;350:h2975.

62. Verma R, Khanna P. Tetanus toxoid vaccine: elimination of neonatal tetanus in selected states of India. Hum Vaccin Immunother. 2012;8:1439-42.
63. Cherry JD, Tan T, Wirsing von Konig $\mathrm{CH}$, Forsyth $\mathrm{KD}$, Thisyakorn U, Greenberg D, et al. Clinical definitions of pertussis: summary of a Global Pertussis Initiative roundtable meeting, February 2011. Clin Infect Dis. 2012;54:1756-64. 